\title{
A social ecological model (SEM) to exploring barriers of and facilitators to the implementation of Opioid Agonist Treatment (OAT) programmes in prisons
}

\begin{tabular}{|r|l|}
\hline Journal: & International Journal of Prisoner Health \\
\hline Manuscript ID & IJPH-04-2020-0020.R2 \\
\hline Manuscript Type: & Research Paper \\
\hline Keywords: & $\begin{array}{l}\text { methadone programmes, prisons, opioid agonist treatment, qualitative } \\
\text { studies, low-middle income countries, social ecological model }\end{array}$ \\
\hline \multicolumn{2}{|l}{} \\
\hline
\end{tabular}

\section{SCHOLARONE" \\ Manuscripts}

Publisher policy allows this work to be made available in this repository. Published in International Journal of Prisoner Health by Emerald. The original publication is available at: https://doi.org/10.1108/IJPH-04-2020-0020 This article is deposited under the Creative Commons Attribution Non-commercial International Licence 4.0 (CC BY-NC 4.0). Any reuse is allowed in accordance with the terms outlined by the licence (https://creativecommons.org/licenses/bync/4.0/. To reuse the AAM for commercial purposes, permission should be sought by contacting permissions@emeraldinsight.com. 


\section{A social ecological model (SEM) to exploring barriers of and facilitators to the implementation of Opioid Agonist Treatment (OAT) programmes in prisons}

\section{Introduction}

Opioid agonist treatment (OAT), an evidence-based treatment for opioid dependence, has been associated with reductions in illicit drug use, injecting drug use, the sharing of injecting equipment and an increase in adherence to antiretroviral therapy (ART) (Springer and Bruce 2008; Wolfe et al. 2010; Hedrich et al. 2012). OAT in prisons therefore, plays a significant role in preventing human immunodeficiency virus (HIV) and Hepatitis $\mathrm{C}$ virus (HCV) transmission through the reduction of unsafe injecting practices (Kinner et al. 2013; Jürgens et al. 2009; Azbel et al. 2018). However, despite its proven effectiveness, the availability and coverage of prison OAT programmes remain low. By 2016 , only 80 out of 158 countries, where injecting drug use was reported, had implemented OAT programmes (Harm Reduction International 2016). OAT implementation in prisons was even lower. Only 29 countries provided such programmes in 2008 (Larney 2009).

\section{HIVIAIDS issues and the Indonesian responses}

Studies show that prisoners, especially injecting drug users, are at greater risk of exposure to HIV infection in prison settings (Larney et al. 2017; Altice et al. 2016). These risks are linked to continuing injecting drug use and the practice of sharing unsterile injecting equipment in prisons (Izenbergh 2014; Zamani et al. 2010). Indonesia is witnessing a concentrated HIV epidemic with a prevalence rate of $29 \%$ among injecting drug users (UNAIDS 2018). In 2008, it was estimated that there were 3.4 million people who use drugs in Indonesia, of whom $7 \%$ inject drugs, with heroin 
among the most commonly injected drugs (National Anti-Narcotics Agency of the Republic of Indonesia 2009). In 2010, the Indonesian Ministry of Justice (MOJ) found that HIV prevalence rates in the prison population ranged from $8 \%$ in general prisons to over $33 \%$ in narcotics prisons (Directorate of Corrections 2010). This variation perhaps reflects the different types of prison in Indonesia (narcotics and general prisons) and their location (urban and rural). Studies have reported increasing numbers of HIV cases associated with injecting drug use in Indonesian prisons from $37.6 \%$ in 2010 (Nelwan et al. 2010) to $56 \%$ of cases in 2015 (Culbert et al. 2015). The latter study also found that $94.5 \%$ of prisoners with HIV reported sharing contaminated injecting equipment (Culbert et al. 2015).

In response, the Indonesian government launched HIVIAIDS prevention programmes including OAT programmes in both community and prison settings. Indonesia was also the first Asian country to include prisons within its Strategic Plan (Directorate of Corrections 2005). However, unlike in community settings, Indonesian prisons did not adopt needle and syringe programmes (NSPs) on safety and moral grounds. The first OAT programmes were established in a community hospital in Bali in 2003 (National AIDS Commission 2009), while the first prison OAT programmes were introduced in Kerobokan prison (also in Bali) in 2005, with methadone as the only drug offered (Ministry of Health Indonesia 2008).

Imprisonment as a response to drug use is common in many Asian countries (Degenhart et al. 2010; Mustafa in press), including Indonesia. Although Narcotics Law No. 35 of 2009 supported the provision of medical and social rehabilitation for people who use drugs, the criminalisation of drug users has increased after a new law was passed in 2012 that imposes severe penalties on drug offenders (Narcotics Law No. 
35 of 2009). Therefore, alleged and convicted drug users are commonly imprisoned.

This has resulted in severe overcrowding, with some prisons running at $260 \%$ capacity (Directorate of Corrections 2016).

Drug law enforcement policy and the massive incarceration of drug users has negatively affected the availability of, and access to, OAT programmes as indicated in other countries (Kamarulzaman 2009a; Hayashi et al. 2017). By 2016, 12 out of 412 Indonesian prisons had established OAT programmes, however, the overall uptake was very low and only served an estimated 69 prisoners in 2016 (Directorate of Corrections 2017). A US study by Friedmann (2012) reports that low uptake of OAT programmes in prisons is often associated with negative attitudes among prison staff, safety concerns, a drug-free treatment philosophy in prisons, as well as a lack of resources.

Little is known about the delivery of OAT programmes in Indonesian prisons. This qualitative study aimed to understand the role of Indonesian OAT programmes in the context of HIV prevention programmes by using the social ecological model (SEM) as an analytical lens. The study comprised three different Indonesian prisons and incorporated interviews with prison governors, security staff, healthcare staff and prisoners. It provides an in-depth understanding of the barriers to and facilitators of the delivery of programmes at the intrapersonal, interpersonal, and social-structural levels in this middle-income country setting.

\section{Social Ecological Model (SEM)}

As noted, this study employed the SEM model that examines interdependences between intrapersonal, interpersonal, institutional, community factors and public policy 
(McLeroy et al. 1988). This model has been previously applied in research into HIV risk behaviours among people who inject drugs because of its holistic approach and recognition of the complexity of personal and social circumstances (Mburu et al. 2019). The model allows for the exploration of multiple contributing factors to complex situations and for the identification of potential strategies for improvement in these settings (Gombachika 2012; Baral et al. 2013). This study drew on the SEM model in order to incorporate multilevel analyses and to understand what types of interventions might mitigate barriers to the implementation of OAT programmes in prisons.

\section{Setting}

Indonesia was chosen for this study due to the high prevalence of drug use and HIV in prisons mentioned above. Indonesian prisons are classified by security levels, whichrange from low to maximum security; prisoner gender (male or female); age (children, youth, or adult), and offense (narcotics or non-narcotics prisons). In 2016, there were 33 narcotics prisons out of a total estate of 412 prisons (Directorate of Corrections 2017).

The Ministry of Justice and Human Rights (MoJ) supervises prisons, while the Ministry of Health $(\mathrm{MOH})$ and external agencies, such as international or local nongovernmental organisations (NGOs), mainly support the delivery of HIVIAIDS programmes in prisons. At the time of the study in 2016, only methadone was prescribed in Indonesian OAT programmes. 


\section{Methods}

\section{Design and sampling methods}

The importance of understanding cases within their specific contexts is the primary concern of a case study (Stake 2005). A qualitative case study approach was adopted in this study to provide an in-depth exploration of the complexities of prison settings and their influence on the delivery of methadone programmes.

Three prison settings were selected for the case study in the capital city of Indonesia, Jakarta. Their selection was based on numbers of drug users, prevalence of HIV infection and the availability of methadone programmes. The final sample included a narcotics prison with a methadone programme, a general prison with a methadone programme and a general prison with no methadone programme. The number of prisoners receiving methadone in the two study prisons where OAT was available was 17 and 45 participants, out of approximately 2300 and 2600 prisoners, respectively. This approach allowed for an in-depth comparison between the settings and for any essential differences to be highlighted.

Potential eligible participants were recruited in each prison through purposive sampling, with the help of the chief of security and healthcare staff. Snowball sampling was also employed to minimise participant selection bias.

\section{Selection criteria for study participants}

Prison staff participants were selected based on their current roles and responsibilities. Methadone prisoners were selected based on their participation in the methadone programme, while non-methadone prisoners were selected if they were current 
injecting drug users or had injected drugs for more than six months prior to their incarceration.

\section{Ethical approval and consent to participate}

The study received ethical approval from the University Research Ethics Committee, University of Stirling. There are no procedures for gaining ethical approval from the Indonesian Ministry of Justice and Human Rights (MoJHR). To obtain access to the prison service, a letter of recommendation from the MoJHR was first obtained and sent to each of the prisons selected as potential study sites. An approval letter giving permission to access the study prisons was then signed by each of the three prison governors.

Both written and verbal consent regarding their willingness to participate in the study were obtained from each participant prior to interview. Time was taken over this process to ensure that participants were not coerced and no monetary incentives were offered. Protecting the confidentiality of both study participants and the prisons involved in the study was a priority. Therefore, no identifying information that could lead to any potential harm to individuals or to the reputations of the prisons, was disclosed in any reports, or to any other party including the prison authorities.

\section{Data collection}

In-depth face-to-face interviews were employed to collect data for this study and took place between December 2015 and March 2016. Interviews were conducted with a range of prison stakeholders including prison governors, security staff, healthcare staff and both methadone and non-methadone prisoners. 
Interviews were conducted in a private room or convenient place for the participant. Bahasa Indonesian, the official language of Indonesia, was used in all interviews. Four topic guides were developed based on the study themes for each group to allow comparison across sub-groups and prisons. The investigator (first author) translated these guides from Indonesian to English and conducted back-translation from English to Indonesian. All interviews were recorded digitally, except for one with a prisoner and one with a staff member. Hand-written notes were taken in these cases. The interviews lasted for between 30 minutes and 120 minutes. In total, 57 interviews were completed: 3 prison governors, 9 security staff, 10 healthcare staff (including doctors, nurses, and a psychologist), 16 methadone prisoners, and 19 non-methadone prisoners. The total number of prisoner participants in each prison was 17 prisoners in the narcotics methadone prison, 12 prisoners in the general methadone prison, and 6 prisoners in the general non-methadone prison. Table 1 below gives details of the characteristics of the prisoners who participated in the study. 
Table 1. Prisoner characteristics

\begin{tabular}{|c|c|c|c|}
\hline Characteristic & $\begin{array}{c}\text { Narcotics methadone } \\
\text { prison }\end{array}$ & $\begin{array}{c}\text { General methadone } \\
\text { prison }\end{array}$ & $\begin{array}{c}\text { General non-methadone } \\
\text { prison }\end{array}$ \\
\hline \multicolumn{4}{|l|}{ Age } \\
\hline $21-30$ & 3 & 6 & 1 \\
\hline $31-40$ & 10 & 6 & 5 \\
\hline$>40$ & 4 & - & - \\
\hline \multicolumn{4}{|l|}{$\begin{array}{l}\text { Length in } \\
\text { prison } \\
\text { (months) }\end{array}$} \\
\hline$<6$ & 1 & - & - \\
\hline $6-12$ & 6 & 4 & 1 \\
\hline $13-24$ & 7 & 3 & 4 \\
\hline $25-48$ & 3 & 5 & 1 \\
\hline \multicolumn{4}{|l|}{$\begin{array}{l}\text { Methadone } \\
\text { programmes }\end{array}$} \\
\hline Participated & 11 & 6 & - \\
\hline $\begin{array}{l}\text { Not- } \\
\text { participated }\end{array}$ & 6 & 6 & 6 \\
\hline \multicolumn{4}{|l|}{ HIV diagnosis } \\
\hline Diagnosed & 10 & 6 & 6 \\
\hline Not diagnosed & 7 & 6 & - \\
\hline \multicolumn{4}{|l|}{$\begin{array}{l}\text { ART } \\
\text { medication }\end{array}$} \\
\hline In ART & 9 & 5 & 4 \\
\hline Not in ART & 8 & 7 & 2 \\
\hline \multicolumn{4}{|l|}{$\begin{array}{l}\text { Parental } \\
\text { status }\end{array}$} \\
\hline With child & 8 & 2 & 2 \\
\hline Without child & 9 & 10 & 4 \\
\hline \multicolumn{4}{|l|}{$\begin{array}{l}\text { Family } \\
\text { contact }\end{array}$} \\
\hline In contact & 15 & 7 & 3 \\
\hline Not in contact & 2 & 5 & 3 \\
\hline
\end{tabular}

\section{Data analysis}

The recordings of the interviews were transcribed anonymously and translated into English. The transcripts were then coded and analyzed using Nvivo 11 (Brandão 2015). Framework analysis was adopted for this study because of its transparent approach to organising data (Ritchie et al. 2014), while further thematic analysis (Braun and Clarke 2006; Mustafa 2021) was also undertaken. An initial thematic framework was created by identifying key issues, concepts, and themes. The analysis started with the construction of a descriptive account by identifying similarities and differences across cases and within individual cases to identify how the programmes 
worked across systems, together with the identification of similarities and differences across both individual and prison cases. This was followed by seeking explanatory accounts by exploring relationships through mapping connections between categories and searching for explanations within the whole data set. Guided by the social ecology model (Mburu et al 2019), identified facilitators of and barriers to the implementation of OAT programmes in prisons were mapped onto intrapersonal, interpersonal, and organisational factors, as indicated in figure 1.

Figure 1. Social-ecological model of OAT programmes in prisons

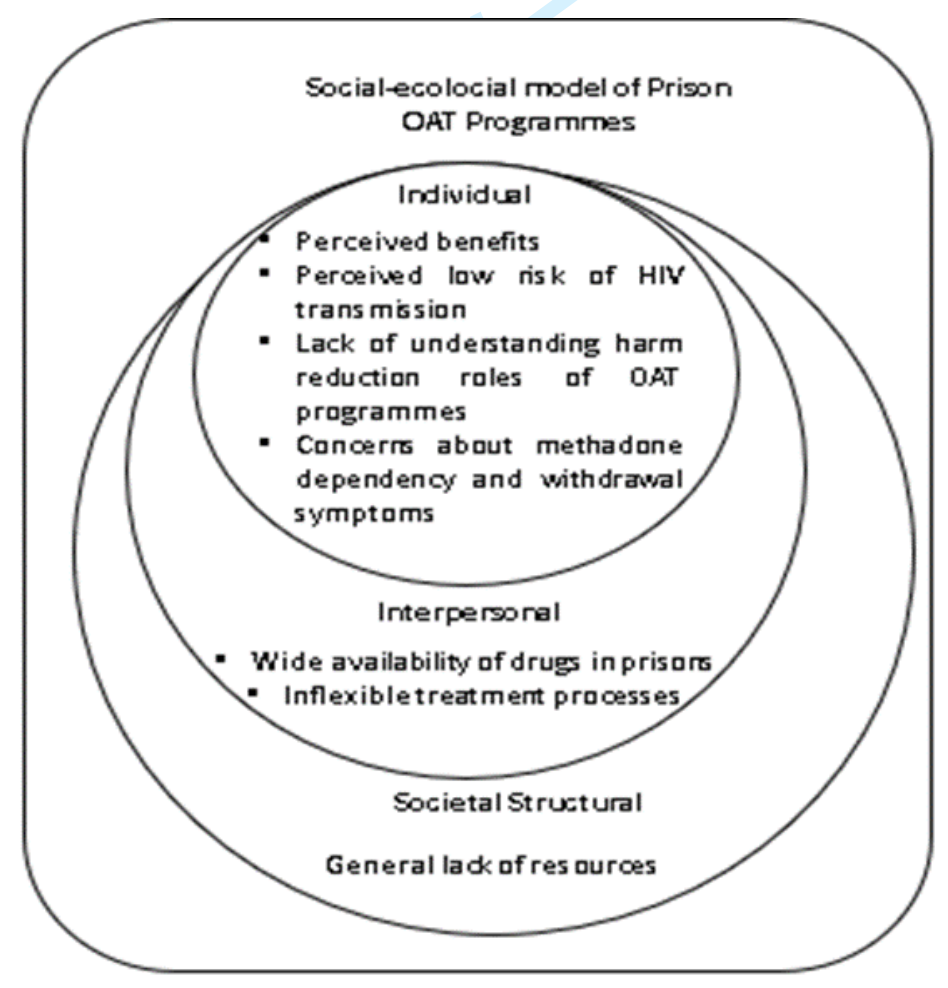

This model is modified from the social-ecological influences of HIV risk (Mburu et al 2019). 


\section{Findings}

\section{Intrapersonal-level factors facilitating the delivery of OAT programmes}

\section{Perceived benefits of OAT programmes in prison}

Both prison staff and prisoners across the three prisons reported the benefits of providing OAT programmes in prisons. For many prison officers, the benefits of the programmes included a reduction in the number of heroin users that regularly inject the drug and a contribution to the management of prisoners:

"Since we have been giving prisoners methadone, they do not need heroin anymore. As far as I know, HIV infection is caused by unsterile needles and syringes when using heroin and, so, HIV transmission was reduced here"

(Narcotics methadone prison, Prison officer, late 20s).

"Prisoners withdrawing from heroin can be a source of disturbance to others and can cause chaos in their cell because of the need for drugs. Being on methadone makes them less tense"

(Narcotics methadone prison, Prison officer, mid 20s)

Both methadone and non-methadone prisoners believed that OAT programmes could bring several health benefits to methadone prisoners, including reductions in the use of injecting equipment and improvements in their quality of life including in their physical, social, financial and mental health conditions. A non-methadone prisoner in the narcotics methadone prison commented on the consequent reduction in the amount of injecting equipment around and how this affected his feelings towards methadone prisoners:

"They used to share syringe needles that cause HIV transmission, and I used to worry about stepping on needles, but now I feel no worries since I do not see any syringe needles here. I do not worry about getting HIV infection, and I feel more relaxed and safer around them"

(Narcotics methadone prison, Non-methadone prisoner, mid 30s). 
Methadone-prisoners from both methadone prisons also noted benefits:

"I found out that methadone brings positive effects to my life -physical and emotional- so there were no reasons why I should decline the methadone"

(General methadone prison, Methadone-prisoner, late 30s).

"We can build a better familial relationship; my family members used to hate me, but now we are tight as a family"

(Narcotics methadone prison, Methadone-prisoner, mid 30s).

"Since methadone is free, so I would not spend money to buy heroin or ask my family for financial support"

(Narcotics methadone prison, Methadone-prisoner, early 40s).

The importance of the latter should not be under-estimated in prisons in lower middle income countries such as Indonesia where prisoners require money for many purposes, including the purchase of adequate food. Overall, however, there were more substantial barriers than facilitators identified to the delivery of OAT programmes in the prisons studied.

\section{Intrapersonal-level barriers to the delivery of OAT programmes}

Interviews suggest that intrapersonal barriers related to misperceptions concerning HIV tranmission and the harm reduction role of OAT programmes, as well as concerns around methadone dependency and withdrawal symptoms.

\section{(Mis)perceptions relating to HIV tranmission in prison}

Many prison staff, across all three prisons, talked about the low risk of HIV tranmission in prison. They perceived that the number of injecting heroin users in prisons was small, that heroin was not widely available and that there was a greater awareness among prisoners of injecting as a risk behaviour for HIV transmission. As the following quote from a senior member of staff illustrates, prison staff's understanding of HIV 
transmission risks was limited to heroin injection and heroin was perceived to be unavailable:

"What I have heard is that the number of people who inject heroin has decreased. It (injecting drugs) is an unpopular method among drug users because they know the risks of doing it. They also say heroin is very rare nowadays" (Prison governor).

A prisoner in the narcotics methadone prison provided an explanation for this (mis)perception that few prisoners were injecting drugs:

"Only the small number of prisoners in the methadone programme are known to the health staff as injecting heroin users, but most of the people who use heroin are unidentified here"

(Narcotics methadone prison, Non-methadone-prisoner, early 30s).

A prisoner from the narcotics methadone prison also indicated that there is an abundant supply of affordable heroin in prison:

"There is much heroin...[and], the price of heroin is much lower than methamphetamine"

(Narcotics methadone prison, methadone-prisoner, early 30 s).

Furthermore, understanding the risks associated with injecting was not sufficient to prevent prisoners from injecting drugs. The degree to which injecting drugs was given priority over the known risks was indicated by a prisoner from the general nonmethadone prison:

"The most important thing people will look for in prison is drugs. I could not refrain from taking heroin. It is my greatest need to inject drugs, so I cannot hold back, even though I know the risks of injecting drugs"

(General non-methadone prison, non-methadone prisoner, late 20s).

\section{(Mis)perceptions of the harm reduction role of OAT programmes}

The majority of the healthcare staff, and some prison officers in the two methadone prisons, showed a relatively good understanding of the aims of the programmes. For example, a member of the healthcare staff commented: 
"Methadone programmes are effective programmes considering their aims, since previously there was much heroin and the number of heroin users was up to $20 \%$. The low level of injecting drug users has only happened recently. I think it is better for them to use methadone instead of injecting heroin"

(Narcotics methadone prison, Doctor, female).

Another explained:

"Prisoners who use heroin typically inject the drug. That is why we have methadone to prevent diseases related to unsafe injecting practices including HIVIAIDS"

(General methadone prison, Doctor, male).

In contrast, with a very few exceptions, healthcare staff in the general non-methadone prison seemed not to recognise the potential risks associated with injecting behaviours in prison. Instead, methadone programmes were considered a lower priority than achieving a drug-free state.

"Some prisoners who took methadone in other prisons and they were being transferred to this prison, could cope with the methadone withdrawal symptoms and have a normal life without methadone and illegal drugs here"

(General non-methadone prison, Healthcare staff, female, early 30s).

Furthermore, across all three prisons, many of the non-methadone prisoners, prison officers and prison governors did not fully understand that methadone programmes had been implemented in Indonesian prisons as part of an HIV prevention strategy. Instead they believed that methadone was provided merely to treat cravings for heroin:

"I think methadone cannot prevent HIV transmission, and it is only a drug to prevent people from heroin withdrawal"

(Narcotics methadone prison, Non-methadone prisoner, mid 30s).

A common misconception among prison staff was that providing methadone was equivalent to providing an illegal drug. Rather surprisingly even one doctor subscribed to this view:

"If we provide methadone, it means we provide illegal drugs since methadone is a heroin replacement"

(General non-methadone prison, Doctor, female). 
Similarly, a prison governor said:

"Methadone is not good as it means letting the prisoners use illegal drugs"

(Prison governor).

\section{Concerns about methadone dependency and withdrawal symptoms}

The majority of prisoners in all three prisons expressed concerns about methadone dependency and withdrawal symptoms, which were often regarded as more severe than heroin dependency and withdrawal. Methadone was seen as a "harder", more harmful drug than heroin and one that was difficult to stop using. These findings suggest that there is a lack of information about methadone as a medical treatment to support reducing heroin dependence:

"The methadone causes heavy drug dependency compared to heroin" (General methadone prison, Non-methadone prisoner, mid 20s).

"Methadone is pure heroin, so its effects are devastating, while our heroin is only dregs of heroin"

(General methadone prison, Non-methadone prisoner, early 30s).

"No, I am not interested in taking methadone as it leads to greater damage to health and makes death come even faster"

(Narcotics methadone prison, Non-methadone prisoner, late 20s).

"It is difficult to stop methadone because the methadone has been in our body for too long, so it needs time to neutralise the methadone. My friend was at $5 \mathrm{mg}$ methadone, but still found it hard to stop "

(Narcotics methadone prison, Methadone-prisoner, mid 30s).

The views of family members reinforced these concerns:

"My family is concerned about methadone because it is like heroin, so that I will end up as methadone dependent"

(General methadone prison, Methadone-prisoner, early 30s).

Concerns about methadone dependency were also reported by some healthcare staff

from the general non-methadone prison:

"We (healthcare staff and prison authorities) had a meeting about methadone, and we (healthcare staff) claimed that the methadone programmes are useless because it makes the prisoners become drug dependent on methadone" 
(General non-methadone prison, Healthcare staff, female, early 30s).

Fear of methadone withdrawal led both to a fear of death and a fear of witnessing death. These fears increased the perceived degree of risk associated with participation, as one prisoner from the narcotics methadone prison put it:

"Many prisoners were afraid to watch the effects of methadone withdrawal on their fellow prisoners. Even if they took 10-20 showers, the symptoms were not reduced for two months. This is quite different with heroin withdrawal effects which are over within a week"

(Narcotics methadone prison, Methadone prisoner, mid 30s).

The belief that methadone withdrawal can result in death was common in both methadone prisons. This belief stems from either personal or others' experiences of seeing prisoners, friends and relatives die. Indeed, most of the prisoners, whether they were taking methadone or not, expressed concerns about dying from methadone:

"Nine out of 10 prisoners would encourage us to stop attending the programme and warn about painful methadone withdrawal symptoms that lead to death"

(Narcotics methadone prison, Methadone-prisoner, early 40s).

"One of the prisoners died the following day after taking methadone, and that traumatised me. Most of my friends who come together to this prison have died in this prison because of that methadone. All of them died here. Thanks to God I am still alive [because I do not take methadone]"

(Narcotics methadone prison, Non-methadone prisoner, early 30 s).

While healthcare staff from the narcotics methadone prison indicated that opportunistic infections relating to HIV were often the underlying cause of death, the sight of corpses in the clinic corridor in the narcotics methadone prison and the emotional reactions of bereaved family members, heightened fears. A methadoneprisoner described a traumatic scene:

"I feel afraid because I have seen too many dead bodies. It frightened me. You know that it was like yesterday, they put the deceased outside (in the clinic corridor), so we could see him, and his relatives came and how they reacted to that. I do not know how to describe my feelings at that time"

(Narcotics methadone prison, Methadone-prisoner, early 40s). 
Apparently, the corpse was that of an HIV patient who had been hospitalised in the clinic treatment room. The staff, who did not consider how the other prisoners might react, had moved the corpse to the corridor for removal by his family since the prison had no specific room for storing corpses. Such fears were reinforced by a lack of medical support during withdrawal:

"I would experience methadone withdrawal symptoms alone at night because the cell was locked. Other prisoners and the prison officers considered it as an unthreatening condition, so we had to wait until the following morning to increase our methadone dose"

(General methadone prison, Methadone-prisoner, mid 20s).

Similarly, others raised concerns relating to the lack of access to methadone while in the segregation unit and limited access to methadone in other prisons:

"Some methadone-prisoners had experienced severe methadone withdrawals because there is no methadone in this prison, and then they were being sent back to their original prison (where methadone programmes are available)"

(General non-methadone prison, Non-methadone prisoner, early 30's)

\section{Interpersonal processes-level barriers to the delivery of OAT programmes}

Interpersonal factors refer to wider availability of drug and inflexible treatment processes in prisons. These factors, together with negative messages received from healthcare staff and the negative influence of peers, friends and family members, weakened support in enhancing the effectiveness of OAT programmes and in supporting implementation and delivery efforts in prisons.

\section{Widespread availability of illicit drugs in prison}

Drug consumption is influenced by the availability of drugs; supply, therefore, is a major driver of drug use in prison. As one prisoner from the general nonmethadone prison observed: 
"Several people are taking illicit drugs [heroin] here, so I started craving, but for example, if there were no drugs here, I would forget about taking them"

(Narcotics methadone prison, Non-methadone prisoner, late 20s).

Another prisoner noted:

"My friends told me it is easy to get illegal drugs in prisons. In every unit, you can find them"

(General non-methadone prison, Non-methadone prisoner, mid 30s).

Many prisoners in all three prisons identified the easy availability of drugs as a significant driver of both prisoners' initiation into use or relapse back to drug use:

"Dealing with cravings for heroin was difficult particularly when you saw your cellmate taking those drugs"

(Narcotics methadone prison, Non-methadone prisoner, late 20s).

A further explanation for the availability of drugs in prison was staff low pay, a point that foregrounds the general lack of resources in the Indonesian prison system:

"We conduct raids, but as the staff are also human beings, they are tempted by the prisoners. The most challenging task here is to supervise staff. If some staff get tempted, they can smuggle drugs into the prison easily despite our advice"

(Prison governor).

$\underline{\text { Inflexible treatment processes }}$

Rigid admission criteria

In the narcotics methadone prison, prisoners who reported that they had been heroinfree for more than three months were ineligible for OAT programmes since the healthcare staff thought they had fully recovered from their drug dependence. Futhermore, the narcotics prison also required family consent for entry into the programme there, as mentioned above. This requirement was justified in terms of increasing the understanding that prisoners' families had of the programmes. However, many prisoners viewed the requirement as a way of avoiding legal liability:

"The doctors were afraid that something bad might happen to them [methadone patients], so their family need to also be responsible for their condition" 
(Narcotics methadone prison, Non-methadone prisoner, late 30s).

In addition, some prisoners could not contact their family members as doing so would reveal their HIV and heroin use status. Many had had no contact with their families for some time for this very reason:

"It is hard to bring our family members here since we are unable to contact them"

(Narcotics methadone prison, Non-methadone prisoner, late 20s).

"They do not want their family members to know they are taking heroin. You know that they [family members] will think you are sick (have HIV)"

(Narcotics methadone prison, Non-methadone prisoner, early 30 s).

Similarly, a member of healthcare staff from the general methadone prison recognised the problem of contacting family members in more general terms:

"If they are rejected for the programmes because of lack of family consent, then they become more deeply involved in drugs [and] that causes harm for other prisoners"

(General methadone prison, Doctor, male).

\section{Assessment processes}

Further barriers related to assessment processes prior to entry onto a programme. In theory, doctors would assess each prisoner's level of opioid dependence and any related risk behaviours. In practice however, priority was given to prisoners with positive drug tests in both prisons with methadone programmes:

"We could not give methadone to those with the negative urine test results since we supposed that they had been clean"

(General methadone prison, Doctor, male).

Paradoxically, this approach may have had the effect of increasing the use of illicit drugs in prison. As one prisoner from the narcotics methadone prison explained:

"The effects of illegal drugs disappear after 3-4 days, so if you want to join the programmes then you should take heroin every 1-2 days before visiting a doctor"

(Narcotics methadone prison, Methadone prisoner, mid 30s) 
At the same time, many prisoners in both methadone prisons felt that assessment processes which included sensitive questions on risk behaviours would discourage many prisoners from applying to join the programmes:

"Prisoners asked when they took drugs for the last time were frightened. They were afraid that they would be also reported to prison authorities"

(General methadone prison, Methadone-prisoner, late 30s).

There were also concerns about the quality of the information provided about methadone at assessment and the lack of follow-up of prisoners referred by healthcare staff:

"A healthcare member staff did not explain anything about methadone's adverse effects. So, I am surprised with what is happening to me [experiencing methadone physical adverse effects] and I want to quit taking methadone"

(General methadone prison, Methadone-prisoner, early 30s).

"I told a nurse that I did methadone while I was in detention, but I did not have any reference letter (from the detention centre). So, I just waited but I never got the confirmation for methadone programmes enrolment"

(General methadone prison, Non-methadone prisoner, mid 20s).

\section{Dispensing practices}

In the general methadone prison, the clinic would usually open at $8.30 \mathrm{am}$ or $9.00 \mathrm{am}$ and close about 30 minutes later. In the narcotics methadone prison, the clinic would usually open at $10.00 \mathrm{am}$. The staff required all methadone patients to be gathered together before dispensing commenced. Most of the methadone-prisoners in the general methadone prison had concerns about the early opening times:

"My friend did not get methadone because he overslept and then found that the clinic was already closed"

(General methadone prison, Non-methadone prisoner, mid 20s)

In contrast, in the narcotics methadone prison, the methadone-prisoners expressed concern at the later (10.00am) opening time, especially for those with additional health needs, for example, prisoners who had HIV or TB: 
"I hope the opening hours can be moved earlier to 8.30 or $9.00 \mathrm{am}$. I am also taking ART so when I wake up, I feel pains"

(Narcotics methadone prison, Methadone-prisoner, early 30s).

Late opening times at weekends were another concern for prisoners from both prisons with methadone programmes. A methadone-prisoner from the general methadone prison noted:

"At the weekends, the healthcare staff are often late, so the methadone clinic opens at 11 am instead of 9 am"

(General methadone prison, Methadone-prisoner, mid 20s).

Such factors were not generally recognised as problematic by healthcare staff. Only one member of the healthcare staff from the general methadone prison recognised that such factors might contribute to the low uptake of the programmes:

"We can see that most of the methadone participants [here] were the referred patients from methadone programmes in detention centres, only a few of the patients were originally from this prison. I do not know whether the issues are in the opening times, staff attitudes or something else"

(General methadone prison, Healthcare staff, female, early 30 s).

Prisoners who had decided not to join the programmes and methadone-prisoners both complained about the need to attend the clinic daily. A prisoner from the general methadone prison raised two issues: boredom and the need to raise income:

"I felt bored at having to come to the clinic every day and to wait longer before all getting together to get the methadone. I am a recidivist, and no one supports me financially. I have to focus on generating income"

(General methadone prison, Methadone prisoner, early 30s).

Many methadone-prisoners were also critical that while the dispensing practices were not organised around their needs, there were still consequences if they arrived late. These consequences included carrying out unpleasant menial tasks, urine drug testing and their methadone being delayed. Prisoners from the general methadone prison explained:

"If we came at 09.01 instead of at 09.00 am, we were told to clean the toilets" (General methadone prison, Methadone-prisoner, early 30s). 
"Their methadone was given in the afternoon as a punishment, so the methadone-prisoners could feel the withdrawal symptoms first before getting their methadone dose"

(General methadone prison, Methadone prisoner, mid 30s).

Another methadone-prisoner from the narcotics methadone prison recounted:

"Once we came late, my friend was questioned and threatened with urine testing. I was afraid, so I chose not to take methadone that day"

(Narcotics methadone prison, Methadone-prisoner, early 30s).

\section{Institutional process-level barriers to the delivery of OAT programmes}

Almost all the prisoner participants pointed to organisational barriers to the delivery of methadone in prisons.

\section{General lack of resources}

Many prisoners reported further negative effects on methadone programmes of the general lack of resources in Indonesian prisons, pointing to low staffing levels and to the lack of health education and training, of psychosocial support services and of basic facilities for prisoners.

\section{Staffing issues}

The problems of delivering the programmes in such under-staffed settings led to a shortage of healthcare staff to dispense methadone at the weekend in both methadone prisons. A member of the healthcare staff from the narcotics methadone prison emphasised:

"There were 60-65 methadone-prisoners, and they were fighting for such simple things such as obtaining their medical files. I was the only woman in the clinic that weekend and, so, I locked the door and called the security staff"

(Narcotics methadone prison, Healthcare staff, female, early 30 s). 
A prison officer from the general non-methadone prison also described the gravity of this situation:

"There are no healthcare staff at night. So many prisoners have died here because of a lack of treatment. We could do nothing because we have no idea how to deal with prisoners who are withdrawing from drugs"

(General non-methadone prison, Prison officer, early 30s).

Another issue was methadone diversion. Prisoners and prison staff often highlighted

a lack of healthcare staff supervision:

"After taking methadone, he [another prisoner] went to the toilet in the clinic to spit out the methadone. The staff did not watch over us, so you can always play these kinds of tricks"

(Narcotics methadone prison, Methadone-prisoner, early 40s).

A healthcare staff member explained:

"The staff sometimes get bored and become careless, although we have a rule, ...for example, after the prisoners have drunk the methadone, we should talk to them to make sure that they have swallowed it, but yes... sometimes the staff forget that "

(Narcotics methadone prison, Doctor, female).

\section{Lack of education and training}

Many prison officers in all three prisons also commented on a lack of training in health-

related issues. An officer from the narcotics methadone prison observed:

"I did not get any TB or HIV information sessions from the MOJ. HIV-related issues were only discussed with other prison officers or prisoners"

(Narcotics methadone prison, Prison officer, late 20s).

However, interviews with others suggested that the MOJ or $\mathrm{MOH}$ provided bi-annual or annual training in health-related issues for some prison officers. Healthcare staff in all three prisons also provided monthly education sessions for prison officers, but it seemed that many prisoners did not or could not attend these sessions:

"I think it would be difficult if it was the healthcare staff here who conducted the training (in prisons). We (prison officers) might not be interested in coming since we also have other tasks"

(General methadone prison, Prison officer, late 20s). 
It also appeared that information about methadone was provided only as an addition

to education sessions for HIV-infected prisoners:

"I got two HIV education sessions while I was here. They also talked a little bit about the aims of methadone, but [the information] was not clear to me" (General methadone prison, Non-methadone prisoner, early 30s).

\section{Psychosocial support services}

Unlike HIV-positive prisoners, drug-addicted prisoners rarely received psychosocial support. A member of healthcare staff from the general methadone prison believed that such problems for prisoners with addictions were insignificant and that they [health-care staff] were, in any case, not the right people to provide such support:

"Some methadone-prisoners sometimes take illicit drugs to deal with their personal problems, but that kind of situation only occurred occasionally, and mostly they would hesitate to talk about that problem with us"

(General methadone prison, Doctor, male).

In contrast, a methadone prisoner recognised his need for such services to deal with previous traumatic experiences:

"I have traumatic experiences of friends' and family deaths related to methadone withdrawal and I need to talk about these problems"

(General methadone prison, Methadone-prisoner, early 30s).

\section{Lack of basic facilities for prisoners}

Many prisoners in all three prisons also expressed concerns relating to the lack of water in their cells, a problem that might also explain why some methadone-prisoners did not take showers since they ran out of water in their units. A prisoner from the narcotics methadone prison described:

"I hope they give more attention to our cell conditions, for example, we used to sleep very close to each other without space for moving; there was no water in the toilet inside our cell and, so, we had to take water from a tap outside our cell every day"

(Narcotics methadone prison, Non-methadone prisoner, late 20s). 


\section{Discussion}

To our knowledge, this is the first qualitative study that has explored the facilitators and barriers to the delivery of prison methadone programmes in Indonesian prisons, and one of the few on this topic overall. The facilitators and barriers to the delivery were clearly presented by using the socio-ecological model (SEM). The study involved a wide range of prison stakeholders including prison governors, prison officers, healthcare staff, and prisoners.

Our findings indicate that the methadone programmes in Indonesian prisons have benefited both prison staff and prisoners. These findings are in line with other studies that report a reduction in drug-related risk behaviours among prisoners as well as improvements in prisoners' overall physical, social, financial and mental wellbeing where such programmes are introduced (Zamani et al. 2010; Moradi et al. 2015; Larney et al. 2017; Grella et al. 2020).

The current study found that unlike prisoners, most prison staff, including healthcare staff in all three study prisons, considered that HIV transmission was no longer a problem in prisons. This perception contrasts with the evidence that HIV transmission is more common in prison settings because of the much higher frequency of sharing injecting equipment (Culbert et al. 2015; Indig et al. 2010; Jürgens et al. 2009). Furthermore, this association has been reported (Dolan et al. 2015) both for prisons situated in high-income countries (Lindblom et al. 2017) and for middle-income countries including Indonesia (Sawitri et al. 2016).

In common with other studies (Stöver and Kastelic 2016, Komalasari et al. 2020; Komalasari et al. 2021), this study found considerable misunderstandings relating to 
the use of methadone programmes as part of an HIV harm reduction strategy among both prison staff and prisoners and across all three study prisons. The idea that methadone is simply another type of illicit drug, was prevalent among most prison officers and some healthcare staff, again across all three prisons. This has also been found in other prison-based studies (Carlin 2005; Asher 2013) leading prison staff and authorities to conclude that methadone programmes are not appropriate in prison settings (Stöver and Kastelic 2016; Mear et al. 2003). In contrast, Rieckman et al. (2010) reported a link between a better understanding of methadone programmes and reduced institutional resistance to prison-based methadone programmes.

Many prisoners in both methadone prisons indicated that they feared methadone withdrawal intensely. They considered it to be much more dangerous than heroin withdrawal and even potentially fatal. These notions presented considerable barriers to programme participation. In Indonesian society, death is often very visible. However, the practice of leaving corpses temporarily in the prison clinic corridor, often for reasons linked to a lack of prison resources, troubled many prisoners greatly. Prisoners in all three study prisons spoke about the trauma of seeing the death of other prisoners and their families' grief and associated it with their own eventual deaths. Similar findings have been reported by Loeb et al. (2014).

In keeping with work on 'risk environments' (Rhodes 2002), greater flexibility in treatment processes could increase access to OAT programmes and prisoner participation. However, difficulties in accessing OAT programmes were clearly illustrated in the narcotics methadone prison, by the requirement for family consent prior to a prisoner's participation. Many drug users are estranged from their families, or their drug-using history may not be known to their families. This requirement 
suggests a lack of recognition of the personal circumstances of many prisoners who use drugs and that greater flexibility might increase participation. This study also found that restrictive clinic opening times contributed to methadone diversion and to highrisk behaviours. Those who missed the clinic would ask for methadone from other methadone-prisoners or take illicit drugs, potentially leading to an increased risk of deaths from methadone overdose (Strang et al. 2005).

This study also indicated difficulties posed by the lack of flexibility in clinic opening times and requirements for daily clinic attendance as reported in previous studies (Sander et al. 2016; Mukherjee et al. 2016). This inflexibility could also exacerbate mental health problems commonly experienced by drug users, including anxiety and insomnia (also see Ross et al. 2015). This was particularly problematic when clinic times clashed with work programme times. Making some money by working was especially important for prisoners who were estranged from their families or had little family support. This finding has not been reported in other studies but it is critical to the experience of prisoners in lower/middle income countries.

In the Indonesian context, incorporating family support and education can play an essential role in shaping programmes and increasing prisoner participation and programme effectiveness. For example, education of family members about OAT programmes may increase prisoner participation by encouraging them to provide consent, financial support and to help the prisoners maintain abstinence from illicit drugs when in prison. In more general terms, the assessment processes adopted, which included sensitive questions on risk behaviours and urine drug-testing, may also deter participation. 
Full and proper consideration of institutional factors is an essential part of any harm reduction strategy. The shortage of prison officers, particularly those with adequate training in drug use and addiction, also contributed to methadone diversion which can lead to methadone withdrawal or potential overdoses of illicit drugs. There was also a shortage of healthcare staff after office hours, which contributed to and reinforced fears about methadone withdrawal among prisoners.

Alongside drug treatment, it has also been recommended that OAT programmes include psychosocial support and provide education, notably about how to manage withdrawal symptoms (Schuckit 2016; Greer et al. 2016). A number of studies (European Monitoring Centre for Drugs and Drug Addiction 2016; Jhanjee 2014) have reported negative impacts resulting from the lack of psycho-social support for OAT programme participants. These impacts included undermining the commitment to changing behaviour, difficulties in achieving drug reduction or drug abstinence and deterioration in physical and mental health. Specific training for healthcare staff should therefore promote understanding of the evidence base for substitution treatment (Thomas and Miller 2007) and the management of drug dependence and mental health problems (Ross et al. 2015). The link between insufficient information about OAT and low satisfaction with OAT, particularly methadone programmes, has also been reported in community settings in Vietnam, another middle-income country (Tran et al. 2012).

Poor prison conditions, including a lack of healthcare services linked to an increased risk of HIV infection, have also been reported in other low income prison contexts, for example Zambia (Simooya 2010). Elsewhere, improved management of prison facilities has long been associated with improved efforts to promote a supportive 
environment for prisoners' health and to protect prisoners' human rights (Baybutt et al. 2014; WHO 2005).

\section{Conclusion}

This study uses the social ecological model to structure findings about facilitators of and barriers to the delivery of methadone programmes. The model highlights the importance of organisational and inter-personal as well as intrapersonal factors. Such an approach is particularly important in the context of the implementation and delivery of methadone programmes in lower/middle income countries, where socio-structural factors, as our study has shown, are so significant. It should also be noted that these groups of factors overlap. Overall, many more barriers than facilitators were identified.

The SEM model also highlights the need to address barriers to the delivery of methadone programmes in prisons at these different levels - intrapersonal, interpersonal and organisational. Therefore, three main strategies for improvement were suggested: i) the development of a comprehensive education programme for prisoners and training programme for all staff, not only healthcare staff but prison officers and senior management as well. Such programmes would, for example, increase understanding of the role of harm reduction programmes; ii) the re-assessment of practices relating to the delivery of methadone (admission, dispensing practices), which would include conducting a comprehensive review of harm reduction strategies in prisons and elaborating the role of family in increasing support for prisoner participation, for example, by giving the family members education on harm reduction strategies; iii) the re-assessment of prison policy to support the delivery of methadone programmes in prisons, for example, by providing psychosocial support services for methadone participants. 


\section{References}

Altice, F. L., Azbel, L., Stone, J., Brooks-Pollock, E., Smyrnov, P., Dvoriak, S., Taxman, F. S., El-Bassel, N., Martin, N. K., Booth, R., Stöver, H., Dolan, K. and Vickerman, P. (2016) The perfect storm: incarceration and the high-risk environment perpetuating transmission of HIV, hepatitis $\mathrm{C}$ virus, and tuberculosis in Eastern Europe and Central Asia. Lancet (London, England), 388 (10050), pp. 1228.

Asher, H. (2013) Methadone prescribing in local prisons in England. Drugs \& Alcohol Today, 13 (4), pp. 234-243.

Azbel, L., Wegman, M. P., Polonsky, M., Bachireddy, C., Meyer, J., Shumskaya, N., Kurmanalieva, A., Dvoryak, S. and Altice, F. L. (2018) Drug injection within prison in Kyrgyzstan: elevated HIV risk and implications for scaling up opioid agonist treatments. International journal of prisoner health, 14 (3), pp. 175-187.

Baral, S., Logie, C.H., Grosso, A., Wirtz, A.L. and Beyrer, C. (2013) Modified social ecological model: a tool to guide the assessment of the risks and risk contexts of HIV epidemics. BMC Public Health. 13 (482).

Baybutt, M., Acin, E., Hayton, P. and Dooris, M. (2014) Promoting health in prisons: a settings approach. Prisons and Health, p.180.

Brandão, C. (2015) P. Bazeley and K. Jackson, Qualitative Data Analysis with NVivo (2nd ed.). Qualitative Research in Psychology, 12, pp. 492-494.

Braun, V. and Clarke, V. (2006) Using thematic analysis in psychology. Qualitative Research in Psychology, 3 (2), pp. 77-101.

Carlin, T. (2005) An exploration of prisoners' and prison staff's perceptions of the methadone maintenance programme in Mountjoy Male Prison, Dublin, Republic of Ireland. Drugs: Education, Prevention \& Policy, 12 (5), pp. 405-416.

Corkery, J.M., Schifano, F., Ghodse, A.H. and Oyefeso, A. (2004) The effects of methadone and its role in fatalities. Human Psychopharmacology: Clinical and Experimental, 19 (8), pp. 565-576.

Culbert, G.J., Waluyo, A., Iriyanti, M., Muchransyah, A.P., Kamarulzaman, A. and Altice, F.L. (2015) Within-prison drug injection among HIV-infected male prisoners in Indonesia: a highly constrained choice. Drug and Alcohol Dependence, 149, pp. 7179.

Degenhardt, L., Mathers, B., Vickerman, P., Rhodes, T., Latkin, C. and Hickman, M. (2010) Prevention of HIV infection for people who inject drugs: why individual, structural, and combination approaches are needed. The Lancet Infectious Diseases, 376 (9737), pp. 285-301. 
Directorate of Corrections (2017) The Directorate of Corrections database system. Jakarta: Ministry of Justice and Human Rights of Indonesia. Available: http://smslap.ditjenpas.go.id/public/grl/current/monthly/year/2017/month/7.

[Accessed: 12 February 2018].

Directorate of Corrections (2016) The Directorate of Corrections database system. Jakarta: Ministry of Justice and Human Rights of Indonesia. Available: http://smslap.ditjenpas.go.id/public/grl/current/monthly/year/2017/month

17 . [Accessed: 12 February 2018].

Directorate of corrections (2010) HIV and syphilis prevalence and risk behaviour study among prisoners in prisons and detention centres in Indonesia. Available: http://www.spiritia.or.id/dokumen/ibbslapas2010. pdf [Accessed: 14 March 2018].

Directorate of Corrections (2005) The strategic plan on HIVIAIDS and drug abuse in prisons and detention centres in the country Indonesia: 2005-2009. Jakarta: Ministry of Justice and Human Rights of Indonesia. Available: http://www.worldcat.org/title/rencana-strategi-penanggulangan-hivaids dan penyalahgunaan-narkoba-pada-lembaga-pemasyarakatan-danrumah- tahanannegara-di-indonesia-tahun-2005-2009/oclc/298612990. [Accessed: 07 February 2015].

Dolan, K., Moazen, B., Noori, A., Rahimzadeh, S., Farzadfar, F. and Hariga, F. (2015) People who inject drugs in prison: HIV prevalence, transmission and prevention. International Journal of Drug Policy, 26, pp. S12-S15.

European Monitoring Centre For Drugs And Drug Addiction (EMCDDA) (2016) perspectives on drugs. The role of psychosocial interventions in drug treatment. available: http://www.emcdda.europa.eu/system/files/publications/2749/psychoso cial\%20interventions_update\%202016.pdf [accessed: 08 march 2018].

Friedmann, P. D., Hoskinson, R., Gordon, M., Schwartz, R., Kinlock, T., Knight, K., Flynn, P. M., Welsh, W. N., Stein, L. A., Sacks, S., O'Connell, D. J., Knudsen, H. K., Shafer, M. S., Hall, E., Frisman, L. K. and Mat Working Group Of CJ-Dats. (2012) Medication-assisted treatment in criminal justice agencies affiliated with the criminal justice-drug abuse treatment studies (CJ-DATS): availability, barriers, and intentions. Substance abuse, 33 (1), pp. 9-18.

Greer, A.M., Hu, S., Amlani, A., Moreheart, S., Sampson, O. and Buxton, J.A. (2016) Patient perspectives of methadone formulation change in British Columbia, Canada: outcomes of a provincial survey. Substance Abuse Treatment, Prevention, and Policy, 11 (1), p. 3.

Grella, C.E, Ostile, E., Scott, C.K., Dennis, M. and Carnavale, J. (2020) A Scoping Review of Barriers and Facilitators to Implementation of Medications for Treatment of Opioid Use Disorder within the Criminal Justice System. Int J Drug Policy. 81.

Gombachika, B.C., Fjeld, H., Chirwa, E., Sundby, J., Malata, A. and Maluwa, A. (2012) "A Social Ecological Approach to Exploring Barriers to Accessing Sexual and 
Reproductive Health Services among Couples Living with HIV in Southern Malawi". International Scholarly Research Notices, 2012.

Harm Reduction International (2016) The Global State of Harm Reduction 2016. United Kingdoms: Harm Reduction International. Available: https://www.hri.global/files/2016/11/14/GSHR2016_14nov.pdf.[Accessed 13 March 2018].

Hayashi, K., Ti, L., Ayutthaya, P.P.N., Suwannawong, P., Kaplan, K., Small, W. and Kerr, T., (2017) Barriers to retention in methadone maintenance therapy among people who inject drugs in Bangkok, Thailand: a mixedmethods study. Harm Reduction Journal, 14 (1), p. 63.

Hedrich, D., Alves, P., Farrell, M., Stöver, H., Møller, L. and Mayet, S. (2012) The effectiveness of opioid maintenance treatment in prison settings: a systematic review. Addiction, 107 (3), pp. 501-517.

Indig, D., Topp, L., Ross, B., Mamoon, H., Border, B., and Kumar, S. (2010). 2009 NSW inmate health survey: key findings report. Malabar, NSW: Justice Health. Available: http://www.justicehealth.nsw.gov.au/publications/2009-ihs-report.pdf

Izenberg, J.M., Bachireddy, C., Wickersham, J.A., Soule, M., Kiriazova, T., Dvoriak, S. and Altice, F.L. (2014) Within-prison drug injection among HIV-infected Ukrainian prisoners: prevalence and correlates of an extremely high-risk behaviour. International Journal of Drug Policy, 25 (5), pp. 845-852.

Jhanjee, S. (2014) Evidence based psychosocial interventions in substance use. Indian Journal of Psychological Medicine, 36 (2), p. 112.

Jürgens, R., Ball, A. and Verster, A. (2009) Interventions to reduce HIV transmission related to injecting drug use in prison. The Lancet Infectious Diseases, 9 (1), pp. 5766.

Kamarulzaman, A. (2009a) Impact of HIV prevention programs on drug users in Malaysia. J AIDS, 52, pp.17-19.

Kinner, S.A., Jenkinson, R., Gouillou, M. And Milloy, M.J. (2012) High-risk drug-use practices among a large sample of Australian prisoners. Drug Alcohol Depend. 126 (1-2), pp.156-160...DI PAPER MASIH 2013

Komalasari, R., Wilson, S. And Haw, S. (2021). A Systematic Review of Qualitative Evidence on Barriers to and Facilitators of The Implementation of Opioid Agonist Treatment (Oat) Programmes in Prisons. International Journal of Drug Policy. 87, https://doi.org/10.1016/j.drugpo.2020.102978

Komalasari, R., Wilson, S., Nasir, S. and Haw, S. (2020), "Multiple burdens of stigma for prisoners participating in opioid antagonist treatment (OAT) programmes in Indonesian prisons: a qualitative study", International Journal of Prisoner Health, Vol. ahead-of-print No. ahead-of-print. https://doi.org/10.1108/IJPH-03-2020-0018 
Larney, S., Peacock, A., Leung, J., Colledge, S., Hickman, M., Vickerman, P., Grebely, J., Dumchev, K.V., Griffiths, P., Hines, L. and Cunningham, E.B. (2017) Global, regional, and country-level coverage of interventions to prevent and manage HIV and hepatitis $\mathrm{C}$ among people who inject drugs: a systematic review. The Lancet Global Health, 5 (12), pp.1208- 288.

Larney, S., Zador, D., Sindicich, N. and Dolan, K. (2017) A qualitative study of reasons for seeking and ceasing opioid substitution treatment in prisons in New South Wales, Australia. Drug and alcohol review, 36 (3), pp. 305-310.

Larney, S. And Dolan, K. (2009) A Literature Review of International Implementation of Opioid Substitution Treatment in Prisons: Equivalence of Care?. Eur Addict Res ,15, pp.107-112.

Lindbom, S. J., Larsson, M. and Agardh, A. (2017) The naked truth about HIV and risk taking in Swedish prisons: a qualitative study. PLOS ONE, 12 (7).

Loeb, S.J., Penrod, J., McGhan, G., Kitt-Lewis, E. and Hollenbeak, C.S. (2014) Who wants to die in here? perspectives of prisoners with chronic conditions. Journal of Hospice and Palliative Nursing, 16 (3), p. 173.

Mburu, G., Limmer, M. \& Holland, P. (2019) HIV risk behaviours among women who inject drugs in coastal Kenya: findings from secondary analysis of qualitative data. Harm Reduction Journal ,16(10). https://doi.org/10.1186/s12954-019-0281-y

McLeroy, K.R., Bibeau, D., Steckler, A. and Glanz, K. (1988) An ecological perspective on health promotion programs. Health Educ Q. 15 (4), pp. 351-77

Mears, D.P., Winterfield, L.A., Hunsaker, J., Moore, G.E. and White, R.M. (2003) Drug treatment in the criminal justice system: the current state of knowledge. Washington, DC: Urban Institute, Justice Policy Centre.

Ministry of Health Indonesia (2008) Ministerial Decree number 350/Menkes/SK/V/2008 about methadone treatment in hospital. Available: http://bprs.kemkes.go.id/v1/index.php?r=site/pageDyn/id/6. [Accessed 12 March 2018].

Moradi, G., Farnia, M., Shokoohi, M., Shahbazi, M., Moazen, B. and Rahmani, K. (2015) Methadone maintenance treatment program in prisons from the perspective of medical and non-medical prison staff: a qualitative study in Iran. International Journal of Health Policy and Management, 4 (9), pp. 583-589.

Mukherjee, T.I., Wickersham, J.A., Desai, M.M., Pillai, V., Kamarulzaman, A. and Altice, F.L. (2016) Factors associated with interest in receiving prisonbased methadone maintenance therapy in Malaysia. Drug \& Alcohol Dependence, 164, pp. 120-127. 
Mustafa, C. (2021). Qualitative method used in Researching the judiciary: a quality assurance steps to enhance the validity and reliability of the findings. Qualitative Report, 26(1), pp. 176-185. https://doi.org/10.46743/2160-3715/2021.4319

Mustafa, C. (in press). Key Finding: Result of a Qualitative Study of Judicial Perspectives on the Sentencing of Minor Drug Offenders in Indonesia: Structural Inequality. Qualitative Report, 26(5).

National AIDS Commission Republic of Indonesia (2009) Republic of Indonesia country report on the follow up to the Declaration of Commitment on HIVIAIDS (UNGASS) Reporting Period 2008 - 2009. Jakarta. Available: http://files.unaids.org/en/dataanalysis/knowyourresponse/countryprogressreports/20 10countries/indonesia_2010_country_progress_report_en. pdf. [Accessed: 15 March 2018].

Narcotics Law Number 35 of 2009

National Anti-Narcotics Agency of the Republic of Indonesia (2009) Report on the number of drug use: socio-economic disadvantage caused by drug use. Reporting period 2008. Jakarta. Available: https://anzdoc.com/laporan-survei-penyalahgunaannarkoba-

Nelwan, E.J., Van Crevel, R., Alisjahbana, B., Indrati, A.K., Dwiyana, R.F., Nuralam, N., Pohan, H.T., Jaya, I., Meheus, A. and Van Der Ven, A. (2010) Human immunodeficiency virus, hepatitis $B$ and hepatitis $C$ in an Indonesian prison: prevalence, risk factors and implications of HIV screening. Tropical Medicine \& International Health, 15 (12), pp. 1491-1498.

Rhodes, T. (2002). The 'risk environment': a framework for understanding and reducing drug-related harm. International Journal of Drug Policy, 13 (2), pp. 85-94.

Rieckmann, T., Kovas, A.E. and Rutkowski, B.A. (2010) Adoption of medications in substance abuse treatment: Priorities and strategies of single state authorities. Journal of Psychoactive Drugs, 42 (6), pp. 227-238.

Ritchie, J., Lewis, J., Nicholls, C.M. and Ormston, R. (2014) Qualitative research practice: a guide for social science students and researchers. London: Sage.BENERIN DI PAPERNYA

Ross, L.E., Vigod, S., Wishart, J., Waese, M., Spence, J.D., Oliver, J., Chambers, J., Anderson, S. and Shields, R. (2015) Barriers and facilitators to primary care for people with mental health and/or substance use issues: a qualitative study. BMC Family Practice, 16 (1), p. 135.

Sander, G., Scandurra, A., Kamenska, A., MacNamara, C., Kalpaki, C., Bessa, C.F., Laso, G.N., Parisi, G., Varley, L., Wolny, M. and Moudatsou, M. (2016) Overview of harm reduction in prisons in seven European countries. Harm Reduction Journal, 13 (1), p. 28. 
Sawitri, A.A.S., Hartawan, A.A.G., Craine, N., Sari, A.K., Septarini, N.W. and Wirawan, D.N. (2016) Injecting drug use, sexual risk, HIV knowledge and harm reduction uptake in a large prison in Bali, Indonesia. International Journal of Prisoner Health, 12 (1), pp. 27-38.

Schuckit, M.A. (2016) Treatment of opioid-use disorders. New England Journal of Medicine, 375 (4), pp. 357-368.

Simooya, O. (2010) Infections in prison in low and middle-income countries: prevalence and prevention strategies. The Open Infectious Diseases Journal, 4 (1).

Springer, S.A. and Bruce, R.D. (2008) A pilot survey of attitudes and knowledge about opioid substitution therapy for HIV-infected prisoners. J Opioid Manag, 4 (81).

Stöver, H. and Kastelic A. (2016) Drug services and harm reduction practice in prisons. In: Emerging issues in prison health. Dordrecht: Springer, pp.143-167.

Strang, J., Sheridan, J., Hunt, C., Kerr, B., Gerada, C. and Pringle, M. (2005) The prescribing of methadone and other opioids to addicts: national survey of GPs in England and Wales. British Journal of General Practice, 55 (515), pp. 444-451.

Thomas, S.E. and Miller, P.M. (2007) Knowledge and attitudes about pharmacotherapy for alcoholism: a survey of counsellors and administrators in community-based addiction treatment centres. Alcohol and Alcoholism, 42 (2), pp. 113-118.

Tran, BX., Nguyen, NP. (2012) Patient satisfaction with HIVIAIDS care and treatment in the decentralization of services delivery in Vietnam. PloS One, 7.

UNAIDS (2018) Number of people living with HIV. Available: http://aidsinfo.unaids.org/ [Accessed: 05 March 2018].

WHO (2005) Evidence for action: effectiveness of drug dependence treatment in preventing HIV among injecting drug users. Geneva: World Health Organization. Available: http://www.who.int/hiv/pub/idu/drugdependence_final.pdf. [Accessed:05 March 2018].

Wolfe, D., Carrieri, M.P. and Shepard, D. (2010) Treatment and care for injecting drug users with HIV infection: a review of barriers and ways forward. Lancet, 376, pp. 355366.

Zamani, S., Farnia, M., Tavakoli, S., Gholizadeh, M., Nazari, M., Seddighi, A., Setayesh, H., Afshar, P. and Kihara, M. (2010) A qualitative inquiry into methadone maintenance treatment for opioid-dependent prisoners in Tehran, Iran. The International Journal on Drug Policy, 21 (3), pp. 167-172. 